\title{
The Differentiation of Problem Solving Ability by Using Problem Based Learning and Think Pair Share
}

\author{
Lydia Grace Siallagan \\ Mathematics Education Program \\ Graduate program, Universitas Negeri Medan \\ Medan, Indonesia \\ grace.siallagan@gmail.com
}

\author{
Pargaulan Siagian \\ Universitas Negeri Medan \\ Medan, Indonesia
}

\author{
Zul Amry \\ Universitas Negeri Medan \\ Medan, Indonesia
}

\begin{abstract}
Problem Based Learning (PBL) and Think Pair Share (TPS) models used to teach students for problem solving ability. The main of both models lies in the direction of the phase of directing students to actual issues that can improve problemsolving ability. The purpose of this study is to know the difference on student's problem solving ability between whom given PBL with TPS. This study is a quasi-experimental study using an unequal control group design. Research subjects were determined on the basis of random sampling and measurement instruments using description test. Result of measurement of problem solving ability in data form and analyzed using analysis covariance. Hypothesis test method that is used in independent sample F-test. Result at this study at alpha $=0.05$ shown that Faccount $>$ Ftable namely 20.205 $>3.963$, it mean the difference on student's problem solving ability between whom given PBL with TPS.
\end{abstract}

Keywords-PBL, TPS, problem solving

\section{INTRODUCTION}

Mathematics is one of the important subjects that students need at every level of education, because mathematics is a basic science that is widely used in various fields of life and progress of developed countries dominantly dependent on mathematics. However are still there students who feel mathematics as a difficult subject? They think of mathematics as a difficult subject and feared. It is appropriate with Abdurrahman: "from the various fields of study that has been taught in school, mathematics is a study of the most difficult lesson to students are not better learning disabilities and learning difficulties"[1].

The fact in Senoir High School (SMA) teachers used teaching conventional teaching likes presenting subject, giving examples and asking students to do the exercises. Beside that during the learning process, teacher is more active in class while students are passive. When their exercise is given only able to work on the problems similar to those given by the teacher.It is appropriate with [2] says: "during this time in the process of learning mathematics in class, students generally learn mathematics only told by the teacher and not through exploration activities", Based on the description, learning processes like that make students' problem solving abilities are difficult to develop.

Indonesia has included problem solving ability in the mathematics curriculum. Problem solving ability is something think find a way out for something expected, It is appropriate with Polya: "problem solving ability is to problem solving as an attempt to find a way out of a difficulty in achieving a goal that is not immediately achieved" [3], next According to Polya there are four processes including of problem solving ability: First, we have to understand the problem; we have to see clearly what is required. Second, we have to see how various items are connected, how the unknown is linked to the data, in order to obtain the ideas of the solution, to make a plan. Third, we carry out our plan. Fourth, we look back at the completed solution, we review and discuss it [3]. Problem solving ability is very important because "problem-solving ability is the heart of mathematics"[4]. Beside that "problem solving is an integral part of mathematics learning, so it should not be released from mathematics learning"[5]. and "problem solving is so important that it becomes the general goal of teaching mathematics even as the heart of mathematics. The process of thinking in problem solving requires the skill to organize strategy. This will train people to think critically, logically, creatively that is necessary in the face of the future"[2].

Sometimes students assume the material Linear Programming is a difficult lesson to learn. This is supported by a test given at the time of observation the researcher class XI SMA Negeri 5 Medan with questions that test understanding of students' mathematical problem solving. One of the questions used: Cahyo opened a rented business with 2 types of rooms. Type I rooms are rented for IDR 400,000/ month and for type II rooms IDR 500,000 / month. While the land he owns is only enough to make 10 rooms. The cost of making one type I room unit is Rp. 9,000,000.00, while type II is Rp. 12,000,000.00. If the capital owned by Cahyo is Rp. 108,000,000.00 with the assumption that all rooms are filled, then the maximum income that can be obtained by Cahyo every month?

At first it was assumed that students could solve the questions given correctly, because the material had already 
been studied by students. But the reality is very different from what was assumed. From the results of student answers there are only 3 students from 40 only focused search for the answer without making strides in solving the problem. And to resolve the problem solving, there are four steps that must be done, namely: understanding the problem, creating lesson plans, perform calculations, and checking back, 31 students from 40 students have not been able to understand the problem seen from students not being able to make inequality from the sentence the land they have is only enough to make 10 rooms so that students do not continue to solve the problem, and 6 students from 40 students did not answer the question (sheet empty answer).

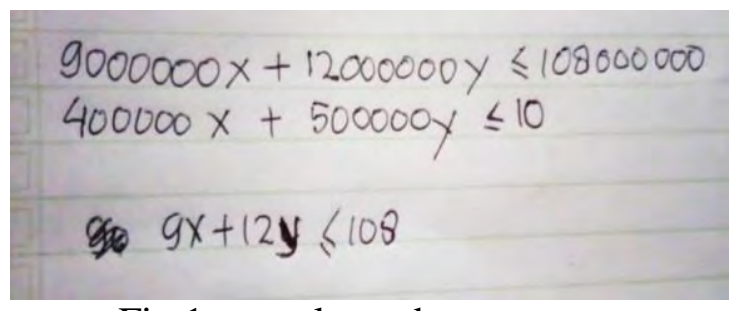

Fig 1. sample student answers

Related to the above description, it is necessary to think about strategies or ways of presenting mathematical material so as to make students active and meaningful learning. One way to develop teaching and learning strategies to students as well as to improve its teaching mathematics is to use a learning model problem based learning (PBL) and think pair share (TPS).

Problem-based learning is learning model that conditions students active in the learning process. Problem-based learning is focused on giving authentic, relevant, and presented problems in a context. According to Arends, "PBL is a model of learning in which students work on authentic problems with a view to construct their own knowledge, develop inquiry and thinking skills, develop independence and confidence" [6]. Trianto said "problem-based learning is a learning model based on the many problems that require authentic scrutiny, ie investigations that require real resolution of real problems"[7].

PBL gives students the opportunity to explore a wide range of information, to link their learning with their own needs as learners, and to develop independence in inquiry. According to Ibrahim, "problem-based learning is not designed to help teachers provide as much material as possible to students, but is developed to help students develop thinking skills, problem solving, and intellectual skills; learn various adult roles through their involvement in real experience or simulation; and become autonomous and independent learning" [7]. Learning theory that underlies problem-based learning with are Dewey, Vygotsky, Bruner and Piaget.

Think pair share learning is model cooperative learning is designed influence student interaction patterns, think pair share is guided students for individual responsibilities and responsibilities in groups or partners. The procedure has been compiled and formed in such a way that it can provide more time for students to be able to think and respond which will generate student participation.
Arends said that "think pair share is an effective way to change the atmosphere of class discussion patterns and control students as a whole which can give students more time to think, to respond and to help each other"[6]. The stages in Think-Pair-Share Cooperative Learning Model techniques are: 1) Thinking, the teacher asks questions and gives the opportunity to think before the students answer the proposed submission. 2) In pairs, the teacher asks students to answer the problem. 3) Sharing, teachers ask pair of students to present their work in front of class while other students give feedbacks for their friends' performances [6]. Learning theory that underlies problem-based learning with are Vygotsky and Piaget.

\section{METHOD}

The type of study used in this study is quasi experiment with study design that used Pretest-Posttest Control Group Design. Arikunto in his book stated "population is the whole subject of study"[12]. In this study population is all students of grade XI in SMA Negeri 5 Medan consisting of fourteen classes. The sample was taken randomly from grade XI as many as two classes, namely class XI-10 and class XI-11 in SMA Negeri 5 Medan, each of which amounted to 40 students. The students of class XI-10 were selected as experimential class I and given the problem based learning while the students of class XI-11 as experimential class II and given the think pair share learning.

Procedure in this study a preparatory phase and the implementation phase. The instrument used in this study is three item of description test (pretest and posttest) which already valid before by three experts in student learning outcomes and through tested by students.

\section{RESULTS AND DISCUSSION}

\section{A. Result}

After conducting learning with two different models, problem-based learning in the experimential class I and think pair share learning in the experimential class II. From the posttest score of two classes, the mean score of experimential class I and experimential class II respectively 78,28 and 71.86, then test the hypothesis by using F-test to determine if there is significant difference in the score or difference is large enough to reject the null hypothesis.

Based on the calculation of hypothesis test, the result is as the following:

TABLE III. RESULT OF HYPOTHESIS TEST

\begin{tabular}{|c|c|c|c|c|}
\hline Sumber & \multicolumn{4}{|c|}{ Sum of Square } \\
\cline { 1 - 4 } Variasi & X & Y & XY & df \\
\hline Treatmens & 13.903 & 824.521 & 107.066 & 1 \\
\hline Error & 6497.819 & 8404.835 & 6245.638 & 78 \\
\hline Total & 6511.722 & 9229.356 & 6352.704 & 79 \\
\hline Sumber & Adjusted & Adjusted & Adjusted & \multirow{2}{*}{ F $_{\text {rasio }}$} \\
\hline Variasi & SS & df & MS & \\
\hline Treatmens & 630.195 & 1 & 630.195 & 20.205 \\
\hline Error & 2401.591 & 77 & 31.189 & \\
\hline Total & 3031.786 & 79 & & \\
\hline
\end{tabular}


From the above table can be seen that F-account $>$ Ftable that is $20.205>3.963$, since F-account $>$ F-table the hypothesis null rejected it means the difference on student's problem solving ability between whom given problem-based learning with think pair share learning on linear programming in grade XI SMA Negeri 5 Medan.

\section{B. Discussion}

In this research, there used two difference model of learning, namely PBL and TPS. Researchers take two classes at random. The first class for experiment class I using PBL and the second class for experimential class II using TPS and each class has 40 students.

Before learning model was given to each class of experiment, first performed a pretest to determine students initial and as a basic for the formation study group. From the research result, the average pretest in experimential class I is 37,5 and average in experimential class II is 36,57. These indication that the two classes can be said have same initial ability because of the result of average pretest both class are small difference. Based on normality and homogeneity testing, two classes were concluded as normality distributed and homogeneous.

This relates to the syntax of the treatment or the steps of the PBL and TPS learning that follows:

- The process of learning experimential classroom I

In experimential class I using PBL. Before the lesson begins the teacher prepares lesson plans and worksheets. Teacher given student problem on worksheets and ask them about problem what understand, interpret and solved problems on the worksheet. Then teacher divide the student into groups with each member has the heterogen that discuss how to solved problem on wirksheets. Teacher determine baseline scores through pretest and group seating arrangements. At each meeting the teacher the teacher give motivation and learning objectives. The teacher provide students with the exposition of material in a demonstration or reading material. The teacher provide tutoring and assigns each group after group discussion result give a presentation in front of class. The teacher give award praise and applause.

- The process of learning experimential classroom II

In experimential class II using TPS. Before the lesson begins the teacher prepares lesson plans and worksheets. Then teacher divide the student discuss problem on worksheets with their pair whom friend beside them, next teacher divide the student to share the results of their discussions with other pair. At each meeting the teacher the teacher give motivation and learning objectives. The teacher provide students with the exposition of material in a demonstration or reading material. The teacher provide tutoring and assigns each pair after pair discussion result give a presentation in front of class. The teacher give award praise and applause.
After being given a different treatment for each class and all the materials are given then last meeting student were given a posttest to determine whether there are differences in problem solving ability of students. Based on result data (posttest) obtained average value 78,28 of experimential class I and average value 71.86 of experimential class II. Of the data there are differences between experimential class I and experimential class II. This proved by the result of statistical calculation where F-account > F-table that is $20.205>3.963$ which means that the difference on student's problem solving ability between whom given problem-based learning with think pair share learning on linear programming in grade XI SMA Negeri 5 Medan which means that the students" problemsolving abilities by using PBL higher than TPS in grade XI SMA Negeri 5 Medan.

\section{CONCLUSION}

Based on the research and processing of data it can be concluded: the difference on student's problem solving ability between whom given problem-based learning with think pair share learning on linear programming in grade XI SMA Negeri 5 Medan which means that the students' problemsolving abilities by using PBL higher than TPS in grade XI SMA Negeri 5 Medan.

\section{REFERENCES}

[1] M. Abdurrahman, "Pendidikan Bagi Anak Berkesulita Berkesulitan Belajar”, Jakarta: Rineka Cipta, 2009.

[2] E.T. Ruseffendi, "Pengantar kepada Membantu Guru Mengembangkan Kompetensinya dalam Pengajaran Matematika Untuk Meningkatkan CBSA (edisi revisi)", Bandung: Tarsito, 2006.

[3] G. Polya, "How To Solve It: A New Aspect of Mathematical Method (2ndEdition)", New York: Princeton University Press, 1957

[4] N.A. Branca, "Problem Solving as A Goal, Process and Basic Skill, dalam Problem Solving in School Mathematics", Reston, VA: NCTM, 1980.

[5] NCTM, "Principle and Standards for School Mathematics", Reaston. VA : NTCM, 2000.

[6] R.I. Arends, "Learning to Teach : Belajar untuk Mengajar", Yogyakarta : Putaka Belajar, 2009

[7] Trianto, "Mendesain Model Pembelajaran InovatifProgresif", Jakarta : Kencana Predana Media Group, 2011. 